TAMARA BRZOSTOWSKA-TERESZKIEWICZ

iD https://orcid.org/0000-0001-5225-3307

Instytut Badań Literackich PAN

tamara.brzostowska@ibl.waw.pl

\title{
HISTORIA STRUKTURALNA, CZYLI DŁUGIE TRWANIE PRZEKŁADU ARTYSTYCZNEGO
}

Jerzy Święch, 2021. Z historii i poetyki przekładu, Lublin: Wydawnictwo Uniwersytetu Marii Curie-Skłodowskiej.

\begin{abstract}
Structural History or the Long Term of Artistic Translation

The article reviews the recent book of Jerzy Święch (Z historii i poetyki przekładu, 2021) as an excellent document of the history of Polish structuralist translation studies. Contrary to what the author modestly suggests, Święch's theoretical statements and historical readings of artistic translations are of much more than solely archival or museal interest. The book contributes to ongoing debates about the ways of studying and writing the history of literary translation in necessary conjunction with, and at the same time independently of, the history of national literatures. Święch's studies invariably serve as guidelines for analyses of artistic translations in the light of historical poetics and the sociology of literature. Many of the biographical and sociological issues raised by the Lublin scholar resonate with recent research tendencies in Translator Studies.
\end{abstract}

Keywords: literary translation history, historical poetics of translation, sociology of literature, translation studies, Translator Studies, modernism studies

Słowa kluczowe: historia przekładu literackiego, historyczna poetyka przekładu, socjologia literatury, przekładoznawstwo, badania nad tłumaczem, studia nad modernizmem 
„Nie ma przesady w stwierdzeniu, że historia literatury stanowi w znacznym stopniu historię przekładu literackiego czy też może historię literatury przekładanej" - pisze Bella Brodzki w rozdziale otwierającym głośną książkę Can These Bones Live? Translation, Survival and Cultural Memory [Czy ożyją te kości? Przekład, przetrwanie i pamięć kulturowa] (2019: 15). O ile podnoszona przez amerykańską komparatystkę kwestia wzajemnych zależności między historiografią literacką a historią literatury tłumaczonej nie budzi większych kontrowersji, o tyle charakter i stopień owych zależności, a przede wszystkim sposoby uprawiania historiografii literackiej oraz przekładowej pozostają kwestią sporną. Wraz z przemianami nowoczesnej i ponowoczesnej teoretycznej refleksji literaturo- i przekładoznawczej narasta bowiem problem delimitacji zakresu przedmiotowego obu dyscyplin wobec historycznie zmiennych definicji , ,iteratury” / „,nie-literatury”, ,przekładu”/ „nie-przekładu” oraz ich wzajemnych stosunków (zob. Reynolds 2018: 23). Czy twórczość przekładowa podlega tym samym procedurom badawczym i kryteriom wartościowania co oryginalna twórczość literacka, czy też jest bytem odmiennym? Czy literaturę przekładową należy traktować jako integralną część historii literatury oryginalnej czy, przeciwnie, domaga się ona odrębnych metod badawczych i swoistego ujęcia historycznego? Czy kategorie, pojęcia i terminy opisu dynamiki procesu historycznoliterackiego powinny być tożsame z instrumentarium pojęciowo-teoretycznym historiografii przekładowej? Czy dzieje literatury oryginalnej i dzieje literatury przekładowej stanowią (pozwalają się kształtować jako) paralelne, linearne, zsymetryzowane, zsynchronizowane przebiegi zdarzeń, czy też przyjmują postać asynchronicznych, arytmicznych, osobliwych układów relacji? „Jak uchwycić i przedstawić [tę - TBT] niezwykle złożoną historyczność przekładu literackiego z jej nakładającymi się warstwami czasu, fałdami i zapętleniami"? - pyta Matthew Reynolds, tropiąc przemiany Literatury w historii (i historii przekładów) (2018: 23).

Nurt rozważań metodologicznych nad możliwościami ukonstytuowania i uprawiania historii przekładu literackiego stale się zmienia, biegnąc równolegle do propozycji metahistoriograficznych i refleksji nad organizacją dyskursu historiografii literackiej. Jakie modele prezentacji historycznej uprzywilejowują historycy literatury? Czy podobnych wyborów dokonują historycy przekładu? Czy historia przekładu literackiego bliższa jest historii zdarzeniowej, czy „długiemu trwaniu” (longue durée), by odwołać się do klasycznego rozróżnienia Fernanda Braudela? Czy model „ekspozycji muzealnej” (periodyzacji literatury oryginalnej/przekładowej wedle stuleci 
bądź dekad) i model „organiczno-dynamiczny”, odzwierciedlający wzrost, dojrzałość i schyłek prądu lub kierunku, są jednakowo przydatne w obu praktykach historiograficznych (zob. Walas 1993)? Czy wreszcie historyk literatury thumaczonej powinien przyjąć „naturalny” porządek chronologiczny, jak w wielotomowym podręczniku The Oxford History of Literary Translation in English podzielonym na okresy odpowiadające periodyzacji historycznoliterackiej właściwej kulturze anglosaskiej ${ }^{1}$, czy może raczej należałoby oddać pole „mikrohistoriom” skoncentrowanym na niszowych, epizodycznych, indywidualnych zdarzeniach w ich „normalnej wyjątkowej transgresyjności wobec mainstreamowych tendencji" (Adamo 2006: $81-82)^{2} ?$

O ile badacze są na ogół zgodni, że przeniesienie uwagi na zagadnienia przekładu artystycznego pozwala przezwyciężyć monolingwizm współczesnej historiografii literackiej (zob. Frank 1998: 18), „przekroczyć wymiar jednej historii lokalnej” (Święch 2021: 23) i zrewidować wiele ustaleń na temat oryginalnej twórczości literackiej, o tyle podają w wątpliwość możliwości syntetycznej realizacji przedsięwzięcia w jednorodnych kategoriach metodologicznych. Szeroko zakrojony projekt historiograficzno-przekładoznawczy, jak w przypadku monumentalnej oxfordzkiej historii przekładu literackiego na język angielski, musi zakładać współpracę wielu ekspertów reprezentujących różne języki, literatury, kultury i metodologie badawcze. Jak pisał Edward Balcerzan:

Nie do pomyślenia jest jedna świadomość, wobec której wedle tych samych lub choćby z grubsza tych samych współodniesień dałyby się przedstawić historie wszystkich polskich tłumaczeń $-\mathrm{z}$ wszystkich obcych literatur. Dlatego nie mamy historii literatury thumaczonej w Polsce. Zamiast syntezy doświadczeń otrzymujemy nagromadzenie przyczynków, które bywają błyskotliwe i mądre, ale nie tworzą całości (Balcerzan 1998: 153)33.

${ }^{1}$ Dotychczas ukazały się cztery tomy: Vol. 1: To 1550 (red. R. Ellis, 2008), Vol. 2: 1550-1660 (red. G. Braden, R.M. Cummings, IS. Gillespie, 2010); Vol. 3: 1660-1790 (red. S. Gillespie, D. Hopkins, 2005); Vol. 4: 1790-1900 (red. P. France, K. Haynes, 2006). Tom V obejmujący wiek dwudziesty jest w przygotowaniu.

${ }^{2}$ W takiej konwencji utrzymana jest np. historia przekładu ukraińskiego spisana przez Maksima Strichę (2006).

${ }^{3}$ Próbę jednoautorskiego, przekrojowego opracowania historii przekładu literackiego w Polsce podjął Wacław Sadkowski: Odpowiednie dać słowu słowo. Zarys dziejów przekładu literackiego w Polsce (2002, wyd. 2: 2013). 
Konieczne zawężenia wymagają trudnych rozstrzygnięć: czy historię przekładów literackich ograniczyć do twórczości jednego tłumacza, szkoły przekładowej, jednego okresu, nurtu historycznoliterackiego, tłumaczeń na jeden język, czy też do wielojęzycznej recepcji jednej literatury, szkoły literackiej, a może pojedynczego autora? A zatem czy w ogóle, a jeśli tak, to $\mathrm{w}$ jakiej perspektywie i na jakich warunkach można uprawiać historię literatury przekładanej? (zob. np. Zarek 2002; Adamczyk-Garbowska 2011). Wreszcie: jakie jest miejsce refleksji historyczno-przekładowej na mapie współczesnego przekładoznawstwa literacko-kulturowego?

Do tych złożonych i wciąż aktualnych zagadnień metodologicznych odnosi się najnowsza książka lubelskiego historyka literatury Jerzego Święcha $Z$ historii i poetyki przekładu, która jest wyborem rozpraw i szkiców zarówno już publikowanych $(Z$ problematyki ttumaczeń parnasistów i Baudelaire'a w Polsce, 1970; Przekład poezji jako sfera ,, interakcji", semiotycznych, 1995; Przekład na warsztacie badacza literatury, 1997; Baudelaire po raz pierwszy, 2015; Kaligramy wojenne Apollinaire'a w przekładach Józefa Czechowicza, 2015), jak i ogłaszanych drukiem po raz pierwszy (Lekcje Camõesa. Przyczynek do historii ttumaczeń; Ptak, co latat do stońca. Z dziejów serii; Postscriptum).

W autorskim wyborze tekstów poświęconych problemom historii i poetyki przekładu artystycznego od razu zaskakuje nieobecność innych studiów uczonego, podejmujących pokrewną problematykę badawczą i stosujących podobne instrumentarium metodologiczne. Chodzi tu przede wszystkim o rozprawy: Ttumaczenie a problemy historii literatury (1972), Model komunikacji przekładowej (1975) oraz Przekład a problemy poetyki historycznej (1976). Rezygnacja z przedruku tych tekstów w recenzowanej książce zdumiewa z dwóch powodów. Po pierwsze dlatego, że publikacji $Z$ historii i poetyki przekładu wyraźnie przyświeca intencja dokumentacyjno-historyczna: chęć utrwalenia i unaocznienia języka XX-wiecznej refleksji przekładoznawczej w przekroju diachronicznym, w tym - dokumentacji własnej drogi badawczej Autora. „Chodziło o to - pisze Jerzy Święch - by dzisiejszemu czytelnikowi zainteresowanemu problematyką przekładów dostarczyć artystycznych dokumentacji do śledzenia dziejów dyscypliny, etapów w rozwoju myśli przekładoznawczej, mającej swoje fazy i okresy" (s. 7)4. Po drugie,

${ }^{4} \mathrm{~W}$ dalszej części artykułu lokalizację cytatów z książki Jerzego Święcha $Z$ historii i poetyki przekładu (2021) podaję bezpośrednio po ich przytoczeniu, wskazując w nawiasie odpowiednią stronę. 
brak trzech wymienionych rozpraw zaskakuje dlatego, że prace przekładoznawcze Jerzego Święcha - znacznie rozciągnięte w czasie i, jak je określa sam Autor, ,przygodne”, ,epizodyczne”, ,drugoplanowe”, poboczne wobec jego zasadniczych zatrudnień historyczno-literaturoznawczych - nie są bynajmniej kolekcją rozproszonych, incydentalnych, peryferyjnych studiów realizujących coraz to inne, nastawione na odmienne wartości modele badania przekładu artystycznego, ale stanowią całkiem pokaźną, wewnętrznie spójną, jednolitą, konsekwentnie rozwijaną całość - wierną wyrazistym wzorcom postępowania badawczego, naznaczoną dobrze rozpoznawalnym stylem autorskim i - co należałoby szczególnie podkreślić - od lat wspóltworzącą kanon polskich prac przekładoznawczych ${ }^{5}$. Uprawiane od ponad półwiecza studia analityczne Święcha o polskich modernistycznych przekładach literackich są nie tylko wzajemnie komplementarne, ale także stanowią nieodzowne dopełnienie i uszczegółowienie rozpraw o charakterze teoretyczno-metodologicznym. Te ostatnie natomiast kapitalnie eksplikują założenia opracowań o nachyleniu analityczno-interpretacyjnym.

Chociaż Jerzy Święch istotnie „unika deklaracji metodologicznych” (s. 8) i eksplicytnych definicji własnego stanowiska teoretycznego, to przecież nietrudno zrekonstruować system założeń, który stanowi o wewnętrznej integralności przekładoznawczego dorobku lubelskiego historyka literatury. Zasadnicze zręby jego stylu badawczego, od Question de la theorie de traduction en Pologne [Zagadnienie teorii przekładu w Polsce] publikowanego na łamach „Slavica Slovaca” (1971) aż po Dzieje ttumaczeń, czyli o historii, której nie ma (2016) i recenzowaną książkę, tworzą, poddane krytycznej rewizji, ustalenia tak zwanej rosyjskiej szkoły formalnej, Praskiej Szkoły Strukturalnej, tartuskiej szkoły semiotycznej (przede wszystkim Jurija Łotmana), polskiej szkoły teorii komunikacji literackiej, nitrzańskiej szkoły przekładu Antona Popoviča, poznańskiej szkoły przekładu, przede wszystkim Edwarda Balcerzana, oraz - bliska obojgu polskim literaturoznawcom - teoria przekładu poetyckiego Jefima Etkinda.

Podstawowy obszar historycznych i teoretycznych zainteresowań przekładoznawczych Święcha określa koncepcja przekładu jako „dzieła sztuki

${ }^{5}$ Potwierdzają to nie tylko liczne odniesienia do rozpraw Jerzego Święcha w polskiej literaturze przekładoznawczej, ale także niedawne przedruki Jego rozprawy w antologiach Polska myśl przekładoznawcza pod red. P. de Bończy Bukowskiego i M. Heydel (2013) (Przektady i autokomentarze, 1984) i Polish Translation Studies in Action. Concepts Methodologies - Applications. A Reader, red. P. Bończa Bukowski M. Heydel (2019) (Translations and Self-Commentaries). 
słowa" (s. 281), a zatem domeny podporządkowanej historycznym regułom, normom i konwencjom artyzmu. W ujęciu lubelskiego badacza studia nad przekładem należą więc przede wszystkim do porządku literaturoznawczego; narzędzi badawczych dostarczają im zarówno poetyka teoretyczna oraz historyczna, jak i rządząca się własnymi prawami ,poetyka przekładu artystycznego" ustanowiona przez Balcerzana ([1968] 1998). Zależności między historią i teorią literatury a historią i teorią przekładów są przy tym obustronne i mają charakter sprzężenia zwrotnego. Jak pisze Jerzy Święch:

Dla każdego zajmującego się refleksyjnie literaturą nie ulega wątpliwości, że problematyka tłumaczeń [...] przynosi w wielu wypadkach odpowiedź na pytania, z jakimi często bezowocnie boryka się historyk i teoretyk literatury pozbawiony możliwości konfrontowania wyników własnych badań poza terenem, który z dawna przywykł uważać za jedyny. [...] Istnieje także relacja odwrotna, gdyż to właśnie te badania często dostarczają praktykom i teoretykom przekładu niezbędnych narzędzi, gdy idzie o optymalizację ich pracy. Teoria przekładu artystycznego [...] pozostaje wciąż dziedziną ,przyliteracką" (s. 9).

W takiej perspektywie badawczej twórczość przekładowa ma status „równorzędnego partnera" (s. 239) twórczości oryginalnej (Święch dobitnie ukazuje to partnerstwo m.in. na przykładzie Józefa Czechowicza jako poety-thumacza kaligramów wojennych Guillaume’a Apollinaire’a), posiadającego własną tradycję i własny kanon dzieł. Badacz podkreśla jednak asynchroniczność przebiegów, a niekiedy nawet różnokierunkowość rozwoju literatury oryginalnej i przekładowej. Podlegając tym samym procesom historycznym, dzieła oryginalne i przekładowe

różnią się pod względem tempa zmian i reagowania na to, co w utworach obcych uchodzi za objaw prawdziwej nowości, a nie przypadek sezonowej mody, co bywa zapowiedzią prawdziwych nowości w literaturze, mimo zupełnie innych warunków, lub jest tylko wyrazem pokusy przyswojenia wzorców uchodzących za obce (s. 280).

Problematykę badawczą lubelskiego historyka przekładu artystycznego wyznaczają kolejne opozycje: modelu twórczości przekładowej i modelu twórczości literackiej, kodu przekładowego i kodu literackiego, komunikacji literackiej i komunikacji translatorskiej, normy przekładowej i normy literackiej, tradycji przekładowej i tradycji literackiej. Inaczej jednak niż prascy i nitrzańscy strukturaliści, Święch wyraźnie rozgranicza modele twórczości literackiej i twórczości przekładowej, nie negując zarazem ich 
ścisłego kontaktu w konkretnej rzeczywistości historycznej (zob. 1976: 364-366). Różnice deskrypcji modelowych twórczości oryginalnej i przekładowej wynikają przede wszystkim z implikowanej przez nie sytuacji komunikacyjnej. Specyfika przekładu polega na tym, że ,jako wypowiedź artykułowana w pewnym kodzie językowym i literackim, skierowana do określonego odbiorcy [...], należy [...] nie do jednego kodu, lecz do obydwu naraz" (Święch 1976: 379).

Wyrazistość i koherencję stylu badawczego Święcha zapewniają także inne założenia, wśród których należałoby wskazać przede wszystkim przekonanie o celowości i intencjonalności uporządkowania zarówno tekstu oryginału, jak i tekstu przekładu, stanowiących całości ,wielokrotnie zakodowane" (s. 265). Podstawowe procedury badawcze obejmują zarówno rekonstrukcję immanentnej poetyki oryginału, jak i analizę porównawczą oryginału i przekładu zakładającą istnienie wielorakich poziomów ekwiwalencji thumaczeniowej (wersyfikacyjnego, gatunkowego, stylistycznego, semantycznego, ideowo-tematycznego itd.). Oryginał zachowuje przy tym status „obowiązującego wzorca” (s. 25) ograniczającego śmiałe ,interpretacje przekładowe" (s. 31). Przekonaniu o normatywnej pozycji oryginału towarzyszy świadomość nieuchronnej arbitralności decyzji translatorskich/ badawczych: „Procedery zmierzające do ujawnienia cech strukturalnych mają charakter posunięć niestandardowych i przez to ryzykownych. Nie ma wszak nigdy dostatecznej pewności, czy odkrycie zasady konstytuującej daną całość [...] istotnie decyduje o trafnym rozszyfrowaniu struktury" (s. 15). Raz odkryty system semantyczny, stylistyczny, gatunkowy, wersyfikacyjny nie tylko oddziałuje na tłumacza, ale także ustawia optykę badacza przekładu.

Trzeba jednak podkreślić, że studia Jerzego Święcha znacznie wykraczają poza model badań strukturalno-semiotycznych skupionych na poetyce, stylistyce i warunkach wielopoziomowej ekwiwalencji przekładowej, wprowadzając elementy socjologii literatury. „Przekład jako fakt świadomości społecznej" (s. 148) rozpatrywany jest w kategoriach społecznego odbioru dzieła literackiego - jako ,projekcja dwóch nierównoległych w swym przebiegu i chronologii porządków: obcych i rodzimych" (s. 148). Uczony uwypukla historycznie i środowiskowo uwarunkowane role thumacza w strategii komunikacyjnej przekładu, rozpoznaje usytuowanie roli tłumacza wobec innych ról społecznych (przede wszystkim pisarza, egzegety, interpretatora, historyka, krytyka), nazywa tendencje społeczno-kulturowe, które kształtują zarówno poczynania translatorskie, jak i style odbioru czytelniczego. 
„Konflikt oczekiwań” tłumacza i czytającej publiczności jest - według Święcha - ,jedną z głównych motywacji tłumaczeń i siłą napędową literatury" (s. 273). Tak profilowany przedmiot badań przekładoznawczych sprawia, że „naturalnym sojusznikiem praktyki i refleksji translatorskiej” (s. 13) stają się współczesne teorie odbioru dzieła literackiego.

Styl badawczych dociekań Święcha wyróżnia wreszcie założenie seryjności jako podstawowego sposobu istnienia przekładu artystycznego ${ }^{6}$. Seria translatorska należy do szczególnie uprzywilejowanych obiektów dociekań historycznoliterackich ponieważ

odbijają się [w niej - TBT] [...] jak w miniaturze procesy charakteryzujące w danym okresie całość produkcji przekładowej, a ruch, jaki się tu odbyw[a], [jest] wyrazem ciągłej zmiany w hierarchii wartości literackich, ale przede wszystkim świadcz[y] o zmianach w samej sztuce przekładu, w stosunku do tradycji przekładowej (s. 28).

Seria przekładowa ukazuje w laboratoryjnej postaci zarówno historyczne konwencje literatury docelowej utrwalone w poszczególnych interpretacjach translatorskich - elementach serii, jak i historycznie zmienne role thumacza. Stanowi także unikatowy zapis ,gry o przetrwanie dzieła obcego w rodzimej kulturze i literaturze" (s. 67) oraz wśród innych konkurencyjnych tłumaczeń dzieła obcego w literaturze docelowej. W światopoglądzie badawczym Święcha konkurencja ta opiera się na zasadach „szlachetnej rywalizacji i tolerancji, jaką jedni tłumacze okazują innym, w istocie bywa miejscem ciągłych sporów i dyskusji” (s. 26). Metafora przekładu jako gry w koncepcji lubelskiego przekładoznawcy to nie tyle (jak w ujęciu Jiř́iego Levý’ego) „proces podejmowania decyzji”, sekwencja „sytuacji-ruchów”, nakładających na tłumacza „konieczność dokonania wyboru spośród pewnej (bardzo często dającej się ściśle określić) liczby możliwości” (Levý 2009: 72), co przede wszystkim wspólnotowe współzawodnictwo oparte wprawdzie na historycznie, kulturowo i środowiskowo określonych regułach, ale dopuszczające znaczną swobodę działania (zob. Święch 1972: 172).

Przyjmując, że normą dla każdego tłumacza jest to, co narzuca tekst pierwowzoru, norma ta w każdym wartościowym przekładzie staje się jedynie punktem startowym do samodzielnej gry z tekstem, jakby to on sam sprawdzał znaczenie i wartość normy, jaką (wcześniej?) ustanawia (s. 208). 1998).

${ }^{6}$ Sformułowane w polskim przekładoznawstwie przez Edwarda Balcerzana ([1968] 
Podążając śladem czeskich i słowackich twórców strukturalnej teorii przekładu, przede wszystkim Felixa Vodički i Antona Popoviča, Święch ujmuje przekład jako jednostkę procesu historycznoliterackiego, analizując go w kategoriach poetyki historycznej. Przekład artystyczny, podlegając immanentnym prawidłowościom procesu historycznoliterackiego, nie tylko odzwierciedla system norm i konwencji rodzimych, ale także wnosi w ów system określony typ innowacji. Podkreślając twórczą (rewolucyjną lub, przeciwnie, konserwatywną) rolę przekładów w procesie historycznoliterackim w kulturze docelowej, badacz łączy innowacyjność tłumaczenia z jego funkcją retrospektywną i reinterpretacyjną: „Czy przekłady nie bywają czasami szansą «korekty» dzieła, olśniewającego jako pomysł i eksperyment, ale dalekiego od pełni swych możliwych urzeczywistnień?" (s. 270). Jeżeli czescy strukturaliści zdecydowanie uprzywilejowywali „awangardowy” model sytuacji historycznoliterackiej, w którym każda inicjatywa translatorska stanowi potencjalne zaprzeczenie zastanych konwencji i źródło artystycznego nowatorstwa (przykładem: klasyczne studium Vodički o Jungmannowskim przekładzie Atali Chateaubrianda jako pierwszym wzorcu czeskiej prozy poetyckiej), to polski historyk przekładu artystycznego przeciwnie - dowartościowuje w postępowaniu badawczym model „epigoński”, podkreślający stabilizacyjną i „homeostatyczną” rolę tumaczeń w procesie historycznoliterackim. Pochyla się nad twórczością przekładową poddaną naciskowi aktualnie obowiązujących norm, konwencji, mód i postulatów współczesnych poetyk, sięgając po egzemplifikacje polskich modernistycznych tłumaczeń francuskich parnasistów Adama M-skiego (Zofii Trzeszczkowskiej), Antoniego Langego, Bronisławy Ostrowskiej, Bogdana Wydżgi, Radosława Okulicza-Kozaryna (Z problematyki ttumaczeń parnasistów i Baudelaire'a w Polsce; Baudelaire po raz pierwszy; Ptak, co latat do stońca. Z dziejów serii) lub portugalski epos narodowy Os Lusíadas Luísa Vaz de Camõesa w odsłonach: pseudoklasycystycznej Jacka Przybylskiego, wczesnomodernistycznej Adama M-skiego oraz współczesnej Ireneusza Kanii (Lekcje Camõesa. Przyczynek do historii thumaczeń). Główni bohaterowie dociekań Święcha, „poddani koniecznościom sytuacji historycznoliterackiej, w której tkwili, naciskowi norm i konwencji, nie spowodowali przewrotu w poezji. Ale jeśli ciągłość sztuki nie ma być frazesem, winniśmy z całą uwagą śledzić wszelkie nawet najdrobniejsze inicjatywy pionierskie, niezależnie od bliższych czy dalszych ich konsekwencji” (s. 158-159). Święch wyjaśnia, że „postęp w sztuce przekładowej” zależy przede wszystkim od ,języka epoki, w której powstał, od stylu, który wciąż jeszcze produkował podobne 
dzieła" (s. 80). Jednym z najistotniejszych zadań historyka przekładu jest zatem właściwe wyważenie proporcji „między klasą wybitnych [tłumaczy], którzy poddają ton melodii, a autorami minorum gentium. [...] Gdyby nie wysiłek całej tej anonimowej dziś dla nas masy przekładowców, nie można byłoby na ich tle ocenić osiągnięć szczytowych" (284). Dopiero przyjęcie takiej perspektywy zapewnia całościowe spojrzenie na dzieje literatury tłumaczonej.

Diachroniczne podejście do przekładu jako nieodłącznej jednostki dziejów literatury narodowej, reprezentowane przez Jerzego Święcha i oparte na propozycjach Popoviča, uprzywilejowuje zatem trzy rodzaje relacji: (a) między oryginałem a przekładem, (b) między przekładem a innymi przekładami tego samego dzieła oraz (c) między przekładem a innymi utworami literackimi w kulturze docelowej. Osobliwości semantyczne thumaczenia wyjaśnia Święch - są pochodną jego usytuowania wobec dwóch systemów norm: tradycji źródłowej oraz dwóch tradycji rodzimych, z których pierwsza obejmuje całą oryginalną literaturę docelową, a druga - przekłady literackie na język docelowy, przy czym, jak dopowiada badacz, tradycja przekładowa może dotyczyć dzieła, autora, gatunku, rodzaju metrum itd. (zob. s. 266). $\mathrm{Z}$ powodu tych wielostronnych uwarunkowań tłumaczenie powinno być rozpatrywane przede wszystkim jako ,proces polegający na optymalizacji rozstrzygnięć: możliwie najlepszych w danej sytuacji” (s. 265)7 . Do najistotniejszych zadań historyka twórczości przekładowej należy natomiast nie tyle analiza porównawcza przekładu i oryginału, co badanie oddziaływania na przekład tradycji literackiej i tradycji translatorskiej w kulturze docelowej, na przykład - jak w klasycznej rozprawie Z problematyki tlumaczeń parnasistów i Baudelaire'a w Polsce - analiza roli barokowej liryki religijnej we wczesnomodernistycznych młodopolskich tłumaczeniach Kwiatów grzechu lub diagnoza wpływu przekładów Alfreda de Vigny'ego na kształtowanie się młodopolskiej koncepcji przekładowej Baudelaire’a.

Eksplorując obszary poetyki historycznej przekładu, Jerzy Święch konsekwentnie „broni strukturalizmu”, by przywołać wymowny tytuł historyczno-literaturoznawczego szkicu badacza (zob. Święch 2006): „Tak czy owak hipoteza dzieła musi być stale obecna w polu zainteresowań tłumacza [i przekładoznawcy - TBT]; właściwie pojawia się na każdym etapie jego pracy jako ostateczny i niepodważalny sprawdzian tożsamości” (s. 10).

7 Warto przypomnieć, że pojęcie optymalności jako kryterium wartościowania przekładu wprowadził Jerzy Ziomek (1975: 47). 
Ponadto, dowodzi historyk literatury, „tłumacz [i przekładoznawca - TBT] nie może pracować efektywnie bez hipotezy autora..." (s. 12). W rozprawach i szkicach Święcha wiara w skuteczność strukturalistycznych narzędzi badawczych oraz przywiązanie do metodologii krytyczno-badawczej opartej na pojęciu ekwiwalencji idą w parze z wyraźną krytyką poststrukturalistycznych postaw teoretycznych, szczególnie „terroru lektury zalecanej przez dekonstrukcjonizm, lansującej tezę o rozproszeniu sensu" (s. 17) oraz tendencji prowadzących do „rozchwiania kryteriów, zamętu metodologicznego, ofensywy dekonstrukcjonizmu itd.” (s. 9). Transgresyjna wielość, „rozmontowywanie tradycyjnych dyscyplin" (s. 277) i (nadmierna) metaforyzacja pojęcia ,przekładu” w studiach kulturowych jawią się jako możliwe zagrożenia dla przedmiotu analizy przekładoznawczej, którym jest dla Święcha „przekład właściwy”. Opowiadając się za racjonalnym i systematycznym podziałem pracy w dyscyplinach humanistycznych, badacz podkreśla wagę analizy tekstowej: „Praca tłumacza jest w ostatecznej instancji pracą nad tekstem...” (s. 288). Przestrzega, że „W dziedzinie tłumaczeń wszelkie pomysły teoretyczne, zwłaszcza te najświeższej daty, mają znikome szanse powodzenia, jeśli w niedostatecznej mierze uwzględniają [tekstową i komunikacyjną - TBT] specyfikę tłumaczeń" (s. 17). Literaturoznawca broni też „właściwej” funkcji przekładu, za jaką uznaje reprezentację oryginału: „Właściwa funkcja tłumaczeń w procesie komunikacji, jaką jest reprezentowanie oryginału, może się realizować jedynie w określonych warunkach historycznoliterackich, kiedy istnieje stałe zagrożenie ze strony funkcji zastępczych, anektujących przekład na terenach mu obcych" (Święch 1976: 371). Źródła tego sposobu myślenia o przekładzie tkwią w czeskiej strukturalistycznej refleksji przekładoznawczej Levý'ego (2011: 20) i Popoviča. Ten ostatni przekonywał: „Przekładowi stawia się warunek, by był funkcją oryginału, tj. by go reprezentował. Inaczej bowiem jego innowacyjna funkcja nie może być realizowana. Inne funkcje przekładu - być pierwowzorem, występować jako utwór, który tai swe pochodzenie, są fałszywe" (Popovič 1973: 123). Uprzedzając zarzuty metodologicznego konserwatyzmu, lubelski translatolog stwierdza autokrytycznie: „Poetyka przekładu artystycznego [...] żywi się nieświadomie pomysłami sprzed lat i nie zawsze bywa up to date" (s. 16-17).

W swoich pracach historyczno-przekładoznawczych Święch nie rezygnuje z tradycyjnych kategorii, jakimi operuje krytyka tłumaczeń: pojęcia normatywności oryginału (,,idealnego dzieła”) i „wierności przekładowej”, ale podkreśla, że „kryteria «dobrego przekładu» są zawsze zrelatywizowane 
wobec czasu, w jakim przekład powstał, i wobec poetyki tłumaczonego dzieła, rozumianego jako struktura cech funkcjonalnie uporządkowanych" (Święch 1972: 71). Z kolei wierność w przekładzie artystycznym „nie polega na próbie odtwarzania tego, co było (gdyż przy użyciu innych narzędzi jest to niemożliwe), ale na zdystansowanym powtórzeniu zasad gry, do której także wciąga się czytelnika” (s. 76). Operując pojęciem ,przekładu poprawnego” badacz podkreśla, że chodzi przede wszystkim o zgodność z założeniami poetyki obowiązującej w danym okresie historycznym, szkole, kierunku literackim itd. Udobitniając napięcie między dwoma językami, dwiema literaturami i dwoma systemami norm w procesie tłumaczenia, Święch uwyraźnia nie tylko asynchroniczność przebiegu procesów historycznoliterackich w kulturach źródłowej i docelowej, ale także specyfikę przekładowej sytuacji komunikacyjnej, w której język docelowy pełni równocześnie funkcje metajęzykowe wobec języka źródłowego. „Sprawiedliwa ocena tłumaczeń" (s. 152) wymaga zatem od krytyka pogłębienia perspektywy historycznoliterackiej.

Ale waga studiów przekładoznawczych Jerzego Święcha nie sprowadza się bynajmniej wyłącznie do znaczenia historyczno-archiwistycznego lub - jak to określa sam Autor - „roli świadectwa i dokumentu czasu” (s. 8), w którym powstały. Najnowszy wybór rozpraw i szkiców badacza dostarcza bowiem nowych, wzorcowych analiz z zakresu poetyki przekładu artystycznego. Z kolei niektóre postulaty teoretyczne Święcha współbrzmią z ideami formułowanymi na gruncie „badań tłumaczoznawczych” (tzw. Translator Studies) rozwijanych od końca lat dziewięćdziesiątych XX wieku, choć nazwiska Andrew Chestermana i Anthony’ego Pyma nie pojawiają się w wyborze prac $Z$ historii i poetyki przekładu. Odwołując się do rozróżnienia typów przekładu proponowanego przez Marilyn Gaddis Rose (1981): zorientowanych na tekst (text oriented) i zorientowanych na czytelnika (reader oriented), Święch przekonuje w jednym z najnowszych szkiców: „... taka dualistyczna koncepcja przywiązana do nowych przekładów winna być poddana rewizji [...] pod kątem samych tłumaczy. [...] Do określeń Gaddis Rose dodalibyśmy trzecie - translator oriented"' (s. 27). Podkreślając znaczenie studiów nad autorskimi poetykami tłumaczy i uprzywilejowując - za Edwardem Balcerzanem - poetykę procesu tlumaczenia, Święch proponuje „uczłowieczenie historii przekładu”, ale - w przeciwieństwie do autora tego postulatu w zachodnim przekładoznawstwie literacko-kulturowym, Anthony’ego Pyma - nie rezygnuje z „tekstologii przekładowej” (s. 288; zob. Pym 1998: ix). 
Jakie są zatem podstawowe założenia ,projektu historii tłumaczeń artystycznych" (s. 277) Jerzego Święcha? Najważniejsze jest dla badacza rozpoznanie, że „,[p]rzekład funkcjonuje równolegle w ramach dwóch historii, tj. literatury docelowej, spełniając tu określone funkcje, oraz jako narzędzie kontaktu [...] między dwoma literaturami/ kulturami, przekraczając ramy historii lokalnej i tworząc wspólnotę dzieł, stylów, konwencji, mód o szerszym zasięgu, europejskim czy wręcz światowym” (s. 18). To właśnie ta podwójna przynależność historyczna i kulturowa decyduje o szczególnej, weryfikacyjno-kontrolnej roli przekładu wobec utrwalonych periodyzacji literackich. Wędrując poprzez epoki i style, ,[k]ażdy przekład staje się [...] propozycją nowej sekwencji historycznoliterackiej, a decyzja tłumacza zawiera w sobie implicite projekt nowego uporządkowania dzieł przeszłości” (s. 18-19). Historyk przekładów traktowanych przede wszystkim jako wyraziste egzemplifikacje ponadlokalnego charakteru stylów, prądów, szkół i konwencji literackich mierzy się z wyzwaniem ,stworzenia historii uniwersalnej, która w istotny sposób modyfikowałaby stosunki panujące na terenach rozmaitych historii lokalnych" (s. 19). Lubelskiemu literaturoznawcy bliska jest koncepcja historii literatury tłumaczonej nie jako „historii zdarzeniowej”, eksponującej pojedyncze, wybitne osobowości twórcze tłumaczy i arcydzieła sztuki przekładu stymulujące ewolucję literacką na drodze gwałtownych zmian, ale jako „historii strukturalnej” (,głębokiej”), by ponownie przywołać Braudelowską opozycję. W perspektywie „długiego trwania" to, co lokalne, jednostkowe, różnolite, efemeryczne, okazuje się jednorodne, powtarzalne, długotrwałe, ponadterytorialne. Postulowana przez Jerzego Święcha historia literatury przekładanej jako „długiego trwania” jest historią struktur (procesów, trendów, koniunktur, cykli), które mogą zostać poznane i opisane za pomocą modeli. Pojęta strukturalnie historia przekładu artystycznego to także historia zmiennych uprawnień i przywilejów tłumaczy jako „wspólnego podmiotu czynności twórczych” (s. 27) w poszczególnych epokach, okresach, kierunkach i nurtach literackich. Jednym z najważniejszych zadań historyka literatury przekładanej jest stworzenie takiego obrazu dziejów, który uwzględnia problemy sekularyzacji, emancypacji, profesjonalizacji i instytucjonalizacji zawodu tłumacza.

Podstawę projektu „historii-której-nie-ma”, by przywołać wyrażenie Autora (2018), stanowi tekstologia, a jego najważniejszym obiektem „nie jest gotowy produkt przekładu, ale wyabstrahowany na jego przykładzie zespół czynności, który doprowadził do jego powstania” (s. 279). Integralną częścią postulowanej historii literatury przekładowej jest - w ujęciu 
Święcha - historia krytyki przekładowej i powiązanej z nią autorefleksji translatorskiej, które pełnią rolę swoistego „pasa transmisyjnego” (s. 283) w komunikacji między tłumaczem a autorem, między tłumaczami oraz między tłumaczami a publicznością literacką. Historia literatury przekładowej pozostaje - w ocenie Święcha - „wciąż brakującym lub niedostatecznie obecnym ogniwem w nieprzerwanym łańcuchu prac nad przekładem" (s. 291), a także, by przywołać diagnozę Antoine’a Bermana, „najważniejszym zadaniem nowoczesnej teorii przekładu" (1992: 1).

Na zakończenie tych uwag trzeba odnotować kwestie natury redakcyjnej. W wyborze studiów $Z$ historii i poetyki przekładu zaskakuje brak indeksu rzeczowego ${ }^{8}$. Rezygnacja $\mathrm{z}$ tego elementu aparatu naukowego znacznie utrudnia korzystanie z książki Jerzego Święcha jako podręcznego źródła wiedzy dla badaczy i studentów przedkładoznawstwa, zgłębiających tajniki poetyki historycznej przekładu literackiego, metodologiczne zagadnienia historii literatury tłumaczonej i dzieje dwudziestowiecznej myśli przekładoznawczej. Sporządzenie indeksu rzeczowego znacznie uprościłoby uściślanie zakresu oraz ustalanie wzajemnych relacji takich kluczowych terminów przywoływanych i ustanawianych przez Jerzego Święcha, jak na przykład awangardowy i epigoński model komunikacji przekładowej, styl przekładowy, model twórczości przekładowej, estetyka przekładu artystycznego, kod przekładowy, komunikacja przekładowa, konflikt oczekiwań, standardy poetyckie, norma przekładowa, obraz tłumacza, obraz historii tłumaczeń, poetyka przekładu, przekład kanoniczny, kodeks tłumaczeniowy, rola tłumacza, seria przekładowa, destrukturalizacja serii przekładowej, sztuka przekładu, tekstologia przekładowa lub tradycja przekładowa. Indeks rzeczowy z pewnością ułatwiłby też ustalanie zakresu zbieżności terminów lubelskiego translatologa i tych stosowanych na przykład w zachodnich systemowych i funkcjonalistycznych podejściach do przekładu literackiego (np. „tradycja przekładowa”/ „kod przekładowy” a „normy przekładowe” Gideona

${ }^{8} \mathrm{Z}$ żalem trzeba też zwrócić uwagę na niedostateczną staranność redakcyjnego opracowania książki: literówki, niekonsekwentny zapis rosyjskich nazwisk i tytułów niezgodny ze współczesnymi zasadami polskiej transkrypcji (B.V. Tomaszewski zamiast B.W. Tomaszewskij), niekonsekwentny (różny w przypisach i w indeksie nazwisk) zapis otczestw przywoływanych badaczy rosyjskich, błędy w tytułach przywoływanej literatury przedmiotu, brak przekładu anglojęzycznych cytatów na język polski oraz błędy w indeksie osobowym i przypisach bibliograficznych (błędna odmiana nazwiska Ingi Iwasiów; francuski literaturoznawca, redaktor Oeuvres complètes Charlesa Baudelaire'a (1961) - Claude Pichois - został przywołany jako C. Oichosi). 
Toury’ego). Wreszcie, indeks rzeczowy pozwoliłby wyeksponować oryginalne, inspirujące metafory teoretyczne Jerzego Święcha takie, jak „wyspy martwego języka" (s. 70) w przekładzie, opisujące fenomen zanikania konotacji w procesie starzenia się thumaczeń, „mowa pozornie bezszmerowa” (s. 115) w komunikacji tłumacza z czytelnikiem na mocy wspólnej wiedzy o świecie lub „wspólny podmiot czynności twórczych” (s. 27) w odniesieniu do grup tłumaczy w poszczególnych epokach, okresach, kierunkach i „,izmach” literackich. Te terminy i metafory badawcze powinny znaleźć należne im miejsce w słowniku przekładoznawstwa strukturalistycznego Europy Środkowo-Wschodniej, który wciąż czeka na napisanie, podobnie jak wielotomowa i wieloautorska historia przekładu literackiego w Polsce.

\section{Bibliografia}

Adamczyk-Garbowska, Monika. 2011. Przekład literacki w Polsce - stan badań nad jego historia i postulaty na przyszłość, „Lingwistyka Stosowana” 4, s. 69-74.

Adamo, Sergia. 2006. Microhistory of Translation, w: G. L. Bastin, P. F. Bandia (red.), Charting the Future of Translation History, Ottawa: University of Ottawa Press, 81-98.

Balcerzan, Edward. [1968] 1998. Poetyka przekładu artystycznego, w: E. Balcerzan, Literatura z literatury (strategie thumaczy), Katowice: „Śląsk”, s. 17-31.

- 1998. Przeklad poetycki w systemie kultury literackiej (Cwietajewa po polsku) [1978], w: E. Balcerzan, Literatura z literatury (strategie tlumaczy), Katowice: „Sląsk”, s. $151-161$.

Braudel, Fernand. 1971. Historia i nauki spoleczne: dtugie trwanie, w: F. Braudel, Historia i trwanie, przeł. B. Geremek, przedmowa B. Geremek, W. Kula, Warszawa: Czytelnik, s. 46-89.

Berman, Antoine. 1992. The Experience of the Foreign. Culture and Translation in Romantic Germany [oryg. 1984], trans. S. Heyvaert, New York: State University of New York Press.

Brodzki, Bella. 2019. Czy ożyją te kości? [org. 2007], przekład zespołowy pod kierunkiem M. Heydel, „Przekładaniec” 39, s. 7-21.

Bukowski, de Bończa Piotr, Heydel, Magda (red.). 2013. Polska myśl przekładoznawcza. Antologia, Kraków: Wydawnictwo Uniwersytetu Jagiellońskiego.

- (red.). 2019. Polish Translation Studies in Action. Concepts - Methodologies - Applications. A Reader Berlin: Peter Lang Internationaler Verlag der Wissenschaften.

Chesterman, Andrew. 2009. The Name and Nature of Translator Studies, „Hermes Journal of Language and Communication Studies" 42, s. 13-22.

Dizdar, Dilek. 2009. Translational Transitions: 'Translation Proper' and Translation Studies in the Humanities, „Translation Studies” 1, s. 89-102. 
Frank, Armin Paul. 1998. Schattenkultur'and Other Well-Kept Secrets: From Historical Translation Studies to Literary Historiography, w: K. Mueller-Vollmer, M. Irmscher (red.), Translating Literature, Translating Cultures: New Vistas and Approaches in Literary Studies, Stanford: Stanford University Press, s. 15-30.

Hermans, Theo. 2015. Narada języków, przekład zbiorowy pod red. M. Heydel i K. Szymańskiej, Kraków: Wydawnictwo Uniwersytetu Jagiellońskiego.

Heydel, Magda, Ziemann Zofia (red.). 2018. Historia przekładu literackiego, „Przekładaniec" 36 i 37.

Levý, Jiř́i. 2009. Przekład jako proces podejmowania decyzji [org. 1966], przeł. M. Adamczyk, w: P. Bukowski, M. Heydel (red.), Współczesne teorie przekładu. Antologia, Kraków: Znak, s. 71-85.

- 2011. The Art of Translation [org. 1963], przeł. P. Corness, red. Z. Jettmarová, Amsterdam - Philadelphia: John Benjamins Publishing Company.

Popovič, Anton. 1973a. Model literárnej komunikacie a překlad, w: A. Popovič (red.), Literárna komunikácia, Martin: Matica slovenská, s. 163-177.

- 1973b. Teoria przekładu w systemie nauki o literaturze, przeł. M. Papierz, w: Małgorzata Czermińska (red.), Konteksty nauki o literaturze, Wrocław: Ossolineum, s. $107-126$.

- 1975. Teoria umeleckého prekladu. Aspekty textu a literárnej metakomunikácie, Bratislava: Tatran.

Pym, Anthony. 1998. Method in Translation History, Manchester: St Jerome.

— 2009. Humanizing Translation History, „Hermes” 42, s. 23-48.

Rajewska, Ewa 2018. Poetyka przekładu wedtug Edwarda Balcerzana, „Forum Poetyki” 14, http://fp.amu.edu.pl/poetyka-przekladu-wedlug-edwarda-balcerzana/ [dostęp: 7 czerwca 2021].

Reynolds, Matthew. 2018, Literatura $w$ historii (i historia przekładów), przeł. Z. Ziemann, „Przekładaniec” 36, s. 7-24.

Rose, Marilyn Gaddis 1981. Translation Types and Conventions, w: M.G. Rose (red.), Translation Spectrum: Essays in Theory and Practice, Albany: State University of New York, s. 31-40.

Sadkowski, Wacław. 2002. Odpowiednie dać słowu słowo. Zarys dziejów przekładu literackiego $w$ Polsce.

Stricha, Maksim. 2006. Ukrajins 'kyj chudożnij pieriekład: miż literaturoju i nacietworienniam, Kijiw: „Fakt”.

Święch, Jerzy. 1971. Question de la theorie de traduction en Pologne, „Slavica Slovaca” 4, s. 292-401.

- 1972. Przekład jako gra [rec. z M. Kurecka: Diabelne tarapaty, Poznań 1970], „Teksty” 3, s. 168-172.

- 1973. [rec. z: A. Drzewiecka, Z zagadnień techniki ttumaczenia poezji. Studia nad polskimi przekładami liryki francuskiej $w$ antologiach z lat 1899-1911, Kraków 1971. „Pamiętnik Literacki” 2, s. 342-348.

- 1974. Ttumaczenie a problemy historii literatury, w: J. Baluch (red.), Z historii $i$ teorii przekładu artystycznego. Materiaty z konferencji naukowej w Szczawnicy, 17-19 marca 1972, Kraków: Uniwersytet Jagielloński, s. 7-24. 
- 1975. Model komunikacji przektadowej, „Teksty” 6, s. 9-22.

- 1976. Przekład a problemy poetyki historycznej, w: H. Markiewicz, J. Sławiński (red.), Problemy metodologiczne współczesnego literaturoznawstwa, Kraków: Wydawnictwo Literackie, s. 360-383.

- 2006. Bronię strukturalizmu, w: W. Bolecki (red.), Dzieła, języki, tradycje, Warszawa: Wydawnictwo IBL, s. 14-27.

— 2016. Dzieje tlumaczeń, czyli o historii, której nie ma, „Postscriptum Polonistyczne” 2, s. 23-30.

- 2021. Z historii i poetyki przektadu, Lublin: Wydawnictwo Uniwersytetu Marii Curie-Skłodowskiej.

Vodička Felix. 1966. Przekład „Atali” Chateaubrianda. przeł. W. Górny, w: M.R. Mayenowa (red.), Praska szkoła strukturalna w latach 1926-1946. Wybór materiałów, Warszawa: Państwowe Wydawnictwo Naukowe.

Walas, Teresa. 1993. Czy jest możliwa inna historia literatury?, Kraków: Universitas.

Zarek, Józef. 2002. Czy możliwa jest historia literatury tłumaczonej?, w: M. Filipowicz-Rudek, J. Konieczna-Twardzikowa (red.), „Między oryginałem a przekładem”, nr 7: Radość tłumaczenia. Przekład jako wzbogacanie kultury rodzimej, Kraków: Księgarnia Akademicka, s. 73-81.

Ziomek, Jerzy. 1975. Kto mówi?, „Teksty” 6, s. 44-55. 